\title{
EFFECT OF SOME INACTIVATION PHYSICAL AND CHEMICAL AGENTS ON VIABILITY, DNA POLYMORPHISM AND GENE TRANSFER ABILITY OF TWO Bacillus thuringiensis BACTERIOPHAGES \\ Youssef, M. A. H. and Amina A. Hassan \\ Genetics Dept., Fac. Of Agriculture, Zagazig University.
}

\begin{abstract}
The inactivation behavior of two Bacillus thuringiensis bacteriophages (A8 and R3) was studied to evaluate their potential as viral indicators for disinfection by heat, UV-C, gamma rays, chlorine, isopropanol and ethanol. The heat effect was highly efficient, PFU/ ml was decreased from $12 \log$ (non- treated) to $1 \log$ at $55{ }^{\circ} \mathrm{C}$ for 90 min, while $60^{\circ} \mathrm{C}$ was completely inactivated at $20 \mathrm{~min}$. It was suggested that this killing effect may due to nucleic acid denatured. UV-C and Gamma irradiation were also dramatically decreased of PFU $/ \mathrm{ml}$. The lowest effect of tested biocides was for chlorine which supplied as sodium hypochlorite, isopropanol come in the second order. The ethanol at $80 \%$ concentration was inactivated all phage A8 population in 90 min and phage R3 in 15 min. In general, phage R3 was sensitive to tested agents than phage A8.

The ability of two inactivated phages to transfer ampicillin resistance gene was studied, this ability was decreased with temperature increased. It was totally inactivated with $60{ }^{\circ} \mathrm{C}$. Two phages were able to transfer the marker gene at all UV-C, Gamma and chlorine treatments. Isopropanol and ethanol were completely inactivated the process, it was suggested that this effect due to alteration of nucleic acid and structure of phages.

The effects of some physical agents (UV-C and gamma rays) only were studied to identify DNA polymorphism through RAPD-PCR analysis in comparison to the control of the two selected bacteriophages. The result of RAPD analysis indicated the appearance of DNA polymorphic bands in response to treatments with doses of all gamma irradiation. Some bands present in the control disappeared in treated bacteriophages or vice versa.
\end{abstract}

Keyword: Inactivation, Bacillus thuringiensis, bacteriophage, radiation, RAPD-PCR

\section{INTRODUCTION}

Bacteriophages have the potential to significantly affect microbial ecology in several distinct ways. Infection of host bacteria resulted in the death of susceptible cells and production of progeny virions. Under laboratory (optimal) conditions, the production of bacteriophage at the expense of host cells can be so efficient that dense, turbid cultures are rapidly cleared due to the lysis of bacterial cells. Thus, under some conditions, bacteriophages may act to destroy sensitive bacterial cell populations.

Bacteriophages are still a major problem in the field of industrial bacterial fermentation. Cheese being one of the most important products affected (Muller et al., 2005). In addition to the potential for dynamic control of bacterial populations and resultant genetic changes exerted due to selection processes. Bacteriophages are likely to be important mediators of genetic 
exchange processes in bacterial populations. The genetic exchange mediated by the direct transport of host genetic material encapsidated in virion particles (transduction) or possible stimulation of cell transformation as a results of cell lysis is both a potential accelerator and confounder of engineered bioprocesses. Evolution was stimulated by genetic exchanges which may aid the adaptation of remediative communities to stress and metabolism of xenobiotic compounds. However, the risk assessment of such process is complicated by the tendency of bacteriophages to disseminate genetic materials, both chromosomal and plasmid. Thermal treatment can be used for inactivation of phages, but some authors affirmed the high heat resistance of phages (Muller et al., 2005).

Irradiation treatment has been proved to be a powerful tool in inactivating human pathogenic microorganisms in water, waste water and sludge, in food and medical products (Farooq et al., 1993 and Lagunas-Solar, 1995). One of the main advantages of such treatment consists of the fact that since irradiation is a physical process, no chemicals have to be added.

Exposure to a chemicals (Biocides) is an effective means to reduce the microbial population, it is widely used method of disinfection and preservation in food and other industries (Peleg, 2002).

Random amplified polymorphic DNA (RAPD) fingerprinting is a modification of the polymerase chain reaction (PCR), which utilises a single arbitrarily-chosen primer to amplify a number of fragments from a given template DNA to generate a discrete "fingerprint" when resolved by gel electrophoresis. Alterations by as little as a single base in the primer sequence lead to marked alterations in the fingerprints generated with a given template under optimized conditions. By inference, single base alterations in the genomic template DNA may also lead to changes in the RAPD fingerprints. RAPD assay was first described by two independent groups (Welsh \& McClelland, 1990 and Williams et al., 1990). RAPD assay is a technique widely used for detecting alterations in DNA sequences induced by mutagenic agents such as gamma rays and is a useful analysis tool for identifying polymorphisms in DNA sequences (Kaberi and Naresh , 1998 and El-Sherbeny et al., 2005). The advantage of RAPD over other techniques is the low technical input and small quantity of DNA needed for the analysis (Hernandez et al., 1999 and Manabe et al., 1999).

The objectives of this study are to investigate the inactivation of two selected bacteriophages, namely A8 and R3 (infecting Bacillus thuringiensis) by some physical and chemical agents and identify DNA polymorphism through RAPD-PCR analysis in comparison to the control of the two selected bacteriophages.

\section{MATERIALS AND METHODS}

This study was carried out in Microbial and Molecular Genetics Lab., Genetics Dept., Fac. of Agric. Zagazig Univ. 


\section{Bacteriophages, bacteria and culture conditions:}

Two Bacillus thuringiensis bacteriophages (A8 and R3) and three $B$. thuringiensis isolates (Bt2, Bt3 and $\mathrm{Bt}$ ) were obtained from Microbial Genetics Lab., Genetic Dept. Faculty of Agric. Zagazig Univ. Bacteria were grown routinely in nutrient agar (NA) and nutrient broth (NB) media at $30{ }^{\circ} \mathrm{C}$ for overnight. Phage propagation and counts were also performed on NA medium at $30^{\circ} \mathrm{C}$ and overnight incubation (Hassan and Youssef, 2011). Phages were enumerated by using double- layer agar method and expressed as plaque - forming unit per milliliter (PFU/ml).

\section{Heat treatments:}

Temperature and time combinations used to identify the thermal effects on phages were $45,50,55$ and $60^{\circ} \mathrm{C}$ for $20,50,80$ and 120 min. Phage suspensions in NB medium were distributed to tubes with a volume of $5 \mathrm{ml}$. These tubes were placed into water bath previously increased to selected temperature. Tubes were transferred to an ice bath immediately to stop the phages inactivation. Subsequently, phages titers were determined. Control counts were identified with the relating phages that were not exposed to thermal treatment (Muller et al., 2005).

UV irradiation:

The phage lysates (volume $10 \mathrm{ml}$ ) were irradiated in sterile Petri dishes (diameter $90 \mathrm{~mm}$ ) under $260 \mathrm{~nm}$ UV- lamp at different times $(0,5,15$, $30,60,90 \mathrm{~min}$ ). Phage PFU/ml was quantified immediately after irradiation.

\section{Gamma irradiation:}

The samples were irradiated in Egyptian Atomic Energy AuthorityNuclear Research Center-Inshas Egypt. The dose rate at time of irradiation was $1.4 \mathrm{KGy} / \mathrm{h}$. Ten $\mathrm{ml}$ of phage lysates were irradiated using $0,200,400$, 600,800 and 1000 KGy

\section{Chemical treatments:}

For chemical inactivation of phages, three biocides were used: chlorine $(0.5$ and $1.0 \mathrm{mg} / \mathrm{ml})$, isopropanol and ethanol (40 and $80 \%)$ at different times $(0,15,30,60$ and $90 \mathrm{~min})$. Chlorine was supplied as sodium hypochlorite, residual chlorine was neutralized by the addition of sodium thiosulphate (Duran et al., 2003). Both alcohols (isopropanol and ethanol) were mixed with phage suspensions in tubes with respect to final concentration of the biocide. At intervals, tubes were removed and the surviving phages were diluted and assayed. For each experiment, nonbiocide- treated phages were used as controls (Buzrul et al., 2007).

\section{Bacteriophages ability to gene transfer:}

With each previous experiments, treated and non- treated phages were subjected to studying their ability to transfer ampcillin resistant gene. One $\mathrm{ml}$ of phage suspension was mixed with $1.0 \mathrm{ml}$ of overnight liquid culture recipient in test tube for $30 \mathrm{~min}$ at room temperature. The mixture was diluted, $0.1 \mathrm{ml}$ was spreaded onto selective medium. After incubation time (25 days), number of transductants were recorded and transduction frequency was calculated (Hassan and Youssef, 2011).

\section{DNA isolation:}

Phages treated with UV and gamma rays only were subjected to DNA isolation and RAPD-PCR. Assays were performed as follows; two hundred 
milliliters of treated phage lysate was incubated for $1 \mathrm{~h}$ at $37^{\circ} \mathrm{C}$. Polyethylene glycol 8000 and $\mathrm{NaCl}$ were added to final concentrations of $10 \%(\mathrm{w} / \mathrm{v})$ and $3 \%$ $(w / v)$, respectively. After gentle mixing, the samples were incubated overnight at $4^{\circ} \mathrm{C}$. Phages were pelleted by centrifugation at $10,000 \mathrm{rpm}$ at $4^{\circ} \mathrm{C}$ for 10 $\mathrm{min}$, and the supernatants were discarded. Phage pellets were resuspended in $100-\mu \mathrm{l}$ of $50 \mathrm{mM}$ Tris (pH 8.0). Phage suspensions were extracted two times with $100 \mu \mathrm{l}$ of phenol and then twice with phenol-chloroform-isoamyl alcohol (25:24:1). Nucleic acids were precipitated with $50 \mu \mathrm{l}$ of $3 \mathrm{M}$ sodium acetate and $1 \mathrm{ml}$ of $70 \%(\mathrm{vol} / \mathrm{vol})$ ethanol and resuspended in $50 \mu \mathrm{l}$ of Tris-EDTA buffer (Prior et al., 2007).

Primers:

A set of 20 primers was analyzed based on the accurate amplified bands profiles of DNA fingerprinting using selected five different primers as shown in (Table 1).

Table 1. Sequence and operon codes of the random primers used to detection of variations in treated bacteriophages.

\begin{tabular}{|l|l|}
\hline Primer codes & Sequence (5 to $\mathbf{3}$ ) \\
\hline OPA-06 & GGT CCC TGA C \\
\hline OPC-08 & TGG ACC GGT G \\
\hline OPC-20 & ACT TCG CCA C \\
\hline OPD-03 & GTC GCC GTC A \\
\hline OPD-05 & TGA GCG GAC A \\
\hline
\end{tabular}

\section{Amplification reaction mixture:}

The amplification conditions were conducted based on Williams et al., (1990) with some modifications. The reaction was prepared using $25 \mu \mathrm{l}$ per tube, containing $2 \mu \mathrm{l}$ DNA of each treatment $(20 \mu \mathrm{g}), 1$ unit of Taq DNA polymerase enzyme, $2 \mu \mathrm{l} 10 \mathrm{X}$ buffer, $2 \mu \mathrm{lgCl}_{2}(25 \mathrm{mM}), 2 \mu \mathrm{l} \mathrm{dNTP}_{\mathrm{s}}(2.5 \mathrm{mM}$ of each), $2 \mu \mathrm{l}$ primer (10 pmol) and $14.8 \mu \mathrm{l} \mathrm{H}_{2} \mathrm{O}$.

\section{DNA amplification cycles:}

The temperature cycling program used with a Perkin-Elmer Gene Amp PCR system (model 2400) was as follows: one cycle at $94^{\circ} \mathrm{C}$ for $5 \mathrm{~min}$ followed by 30 cycles consisting of one step of denaturation $\left(94^{\circ} \mathrm{C}\right)$ for $1 \mathrm{~min}$, one step of annealing $\left(35^{\circ} \mathrm{C}\right)$ for $1 \mathrm{~min}$, followed by one step of synthesis $\left(72^{\circ} \mathrm{C}\right.$ ) for $2 \mathrm{~min}$ and a final extension step consisting of $72^{\circ} \mathrm{C}$ for $7 \mathrm{~min}$ and finally $4^{\circ} \mathrm{C}$ infinitive(Hassan and Youssef, 2011)..

\section{Band analysis:}

Reaction products were analyzed by electrophoresis on $1.4 \%$ agarose gels, stained with ethidium bromide and photographed under UV light. The synthetic DNA, ladder 100 bp (Pharmacia) was employed as molecular markers for bands molecular weight. Each amplified band profile was defined by the presence or absence of bands at particular positions on the gel. Profiles were considered different when at least one polymorphic band was identified. Fragments were scored based on standard marker using GelAnalyzer 3 (Egygene) software. 


\section{RESULTS AND DISCUSSION}

\section{Physical agents inactivation:}

Fig. 1( $a$ and $b$ ) shows the thermal inactivation of phages $A 8$ and $R 3$. Temperature time combination was used in these experiments. Two phages were highly influenced, increase of treatment time for each individual temperature leading to inviability of two phages. The PFU/ml was decreased from $12 \log$ (non- treated) to $1 \log$ at $55^{\circ} \mathrm{C}$ for two phages. Totally inactivated was found by the heat treatment at $60{ }^{\circ} \mathrm{C}$ for all treatment times. Killing of two phages may be due to denaturation of nucleic acid (Bryant et al., 2007). The results presented here are consistent with the results reported in literature (Quiberoni et al., 2003; Bonnie, 2005, Muller et al., 2005 and Buzrul et al., 2007). In general, it is well known that heat effect of phages is species dependent (Muller et al., 2005). The mode of action of heat is denatured capsid proteins, essential enzymes and nucleic acids if temperatures are high to enough (Bonnie, 2005). Bryant et al. (2007) though that DNA itself was denatured because, heat treatment showed notable killing of phage T4.

Fig. 1(c and d) shows the effect of UV and gamma rays on phages A8 and $R 3$ viability. UV radiation is divided into UV-C (below $280 \mathrm{~nm}$ ), UV-B $(280-320 \mathrm{~nm})$ and UV-A (320-390 nm). UV used in this study was from the type UV-C. Bacteriophages were irradiated at different times (dose, 0 - 90 $\mathrm{min}$ ), which dramatically decreased PFU/ml. Phage A8 was reduced from 10 $\log$ to $2 \log$, while $R 3$ from $10 \log$ to $1 \mathrm{log}$. It can be concluded high correlation was appeared between the loss of infectivity and the increase of UV dose. These results are agreed with Sommer et al. (2001) and Said et al. (2009). Ultraviolet light disinfection was being increasingly in treatment of both waste- water and potable drinking water since such treatment does not produce disinfectant by- products (Said et al., 2009). The effectiveness of UV light in biological inactivation are due to the direct DNA damage by inducing the formation of photoproducts pyrimidine dimmer. The accumulation of DNA photoproducts caused cell death if the lesion blocks DNA synthesis and RNA transcription or can be mutagenic if the lesion is by passed by DNA polymerase. This photodimerization process has also been observed with uracil in RNA viruses. However, UV disinfection is noted to have some problems, one of which is reactivation. In response to UV damage, bacteria have developed different repair pathways, including photoenzymatic repair (PER), nucleotide excision repair and recombinational repair. The process of photoreactivation was originally described as the restoration of infectivity to UV- irradiated bacteriophages upon exposure to visible light in the presence of host bacteria (Markus et al., 1997).

For most DNA- viruses, the absence of associated photolyase genes precludes their ability to utilize visible light for repairing UV light-induced genomic damage (Wommack and Colwell 2000). Therefore, any DNA repair dependent on photoreactivation is conditional on successful infection of a host which can provide the necessary enzyme.

Gamma ray was used at different doses: $0,200,400,600,800$ and 1000 Gry. Phage A8 was decreased from 7 log to 2 log, while phage R3 from 
$9 \log$ to $1 \log$. This indicated that nucleic acid is the main target of ionizing radiation, but in viruses the coat also plays an important role. The microorganisms may be affected either by direct (single and double strand breaks) or by indirect reaction (radicals originating from water, mainly $\mathrm{OH}$ free radicals) (Sommer et al., 2001).

Fig. 1. Effect of some physical agents, thermal $(a, b)$ and radiation $(c, d)$ inactivation on viability of phages A8 and R3.

\section{Effect of UV radiation on DNA polymorphism using RAPD-PCR}

RAPD technique was shown to be able in detect mutations (Atienzar et al., 2002, El-Sherbeny et al., 2005, Atienzar and Jha, 2006 and Dhakshanamorthy et al., 2011) and genetic variation at intraspecific level (Palágyi et al., 2004) even though the most common application of RAPD, which has been to determine taxonomic variation and genetic mapping (Dhakshanamorthy et al., 2011). It is suggested that with proper optimization, RAPD could be a sensitive and reliable technique to detect a wide range of DNA damage (Atienzar and Jha, 2006).

In this study, $10 \mathrm{ml}$ of phage lysats were irradiated using UV-C for different times including $0,5,15,30,60$ and $90 \mathrm{~min}$. RAPD assay was employed to detect genomic alterations and it could clearly show that some DNA changes had occurred in treated bacteriophages. 
Evaluation of possibility mutation changes in bacteriophage DNA after the influence of UV-C by RAPD-PCR showed that five out of 20 primers could reveal some polymorphism in the amplified DNA pattern. The total number of amplified fragments from all primers for untreated and each treated bacteriophage with UV-C ray are summarized in Table 2. Each of five different random primers yielded from 3 to 5 DNA fragments whose molecular size ranged from approximately 200 to $900 \mathrm{bp}$. The total number of amplified RAPD fragments after using all five primers was 22 bands with an average of 4.4 fragments / primer. The number of polymorphic bands through each primer ranged from 2 to 5 bands per primer with an average of 3.0 polymorphic bands per primer. The total number of polymorphic amplicons produced by the 5 primers was 15 thus, representing a level of polymorphism of $68.18 \%$ at all. Primer OPD-03 produced the lowest number of fragments (3 bands) among the primers while Primers OPA-06, OPC-20 and OPD-05 produced the highest number of fragments (5 bands). Primer OPC-08 produced the lowest percentage of polymorphism $(50 \%)$, while primer OPC-20 produced the highest percentage of polymorphism $(100 \%)$. It was shown that single nucleotide substitutions in 10- mer primers indeed can be reflected on the amplicons' profiles. The main changes observed in the RAPD profiles have been resulted both in an appearance or disappearance of different bands with variation of their intensity as well. These effects might be connected with structural rearrangements in DNA caused by different types of DNA damages.

The fragment size of the PCR products generated by primer OPD-05 (Figs. 2 and 3) ranged from approximately 200 to 900 bp. Bands with molecular size approximately 350 and 900 bp appeared under the control and treatment for 5 min of UV-C ray in bacteriophage R3 and disappeared under other treatments, while in bacteriophage $A 8$ the two bands disappeared. The appearance of new bands could be attributed to mutation rather than DNA damage (Atienzar and Jha, 2006).

In this study, additional or missing DNA bands were detected due to UV$\mathrm{C}$ radiation and possibly consequent pyrimidin dimmer formation. UV-radiation could produced several major types of DNA lesions such as cyclobutane-type, pyrimidine dimers and the 6-4 photoproducts (Sinha and Hader 2002). Other important types of DNA damages such as protein cross-links, DNA strand breaks, deletion or insertion of base pairs could also be induced by UVirradiation.

UV radiation can change many aspects of plant processes at the physiological and DNA levels (Danon and Gallois, 1998). UV-C radiation has often been used to study various physiologically relevant responses to DNA damages, and in particular it has been shown to induce apoptosis in animal cells. UV-C radiation has also been used to induce apoptosis-like changes in Arabidopsis thaliana (Danon and Gallois, 1998). Jones and Kortenkamp (2000) compared RAPD fingerprints of non-mutant and mutant samples in bacteria and cultured human cells exposed to UV radiation. A dose response in the number of polymorphic bands was seen with UV irradiation of E. coli. 
Table 2. Number of amplicons and the number of polymorphic bands produced by each RAPD primer for control and all bacteriophage treated with UV-C ray.

\begin{tabular}{|c|c|c|c|c|c|c|c|c|c|c|c|c|c|c|c|}
\hline \multirow[b]{2}{*}{ Primers } & \multicolumn{6}{|c|}{$\begin{array}{c}\text { A8 } \\
\text { bacteriophage }\end{array}$} & \multicolumn{6}{|c|}{$\begin{array}{c}\text { R3 } \\
\text { bacteriophage }\end{array}$} & \multirow{2}{*}{ 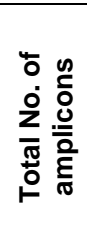 } & \multirow{2}{*}{ 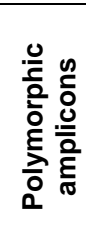 } & \multirow{2}{*}{ 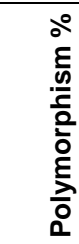 } \\
\hline & $\begin{array}{l}\overline{0} \\
\text { 홍 }\end{array}$ & $\underset{\text { L }}{\stackrel{c}{E}}$ & $\begin{array}{l}\text { 들 } \\
\text { n? }\end{array}$ & $\begin{array}{l}\text {. } \\
\text { E } \\
\text { 유 }\end{array}$ & $\begin{array}{l}\text { 들 } \\
\text { 응 }\end{array}$ & $\begin{array}{l}\text { 돌 } \\
\text { 용 }\end{array}$ & $\begin{array}{l}\overline{0} \\
\text { 홍 } \\
\mathcal{u}\end{array}$ & $\frac{.5}{E}$ & $\begin{array}{l}\text { 들 } \\
\text { م }\end{array}$ & $\begin{array}{l}\text {. } \\
\text { E } \\
\text { 을 }\end{array}$ & $\begin{array}{l}.5 \\
\text { E } \\
\varnothing\end{array}$ & $\begin{array}{l}\text {. } \\
\text { ह } \\
8\end{array}$ & & & \\
\hline OPA-06 & 4 & 3 & 5 & 4 & 5 & 5 & 4 & 3 & 5 & 3 & 5 & 3 & 5 & 3 & 60 \\
\hline OPC-08 & 4 & 4 & 4 & 4 & 2 & 4 & 4 & 3 & 4 & 3 & 3 & 4 & 4 & 2 & 50 \\
\hline OPC-20 & 3 & 3 & 2 & 3 & 2 & 4 & 3 & 4 & 5 & 3 & 3 & 4 & 5 & 5 & 100 \\
\hline OPD-03 & 3 & 3 & 2 & 3 & 3 & 3 & 3 & 3 & 3 & 2 & 3 & 3 & 3 & 2 & 66.66 \\
\hline OPD-05 & 4 & 4 & 3 & 3 & 3 & 3 & 3 & 3 & 3 & 3 & 3 & 3 & 5 & 3 & 60 \\
\hline Total & & & & & & & & & & & & & 22 & 15 & 68.18 \\
\hline Average & & & & & & & & & & & & & 4.4 & 3.0 & \\
\hline
\end{tabular}

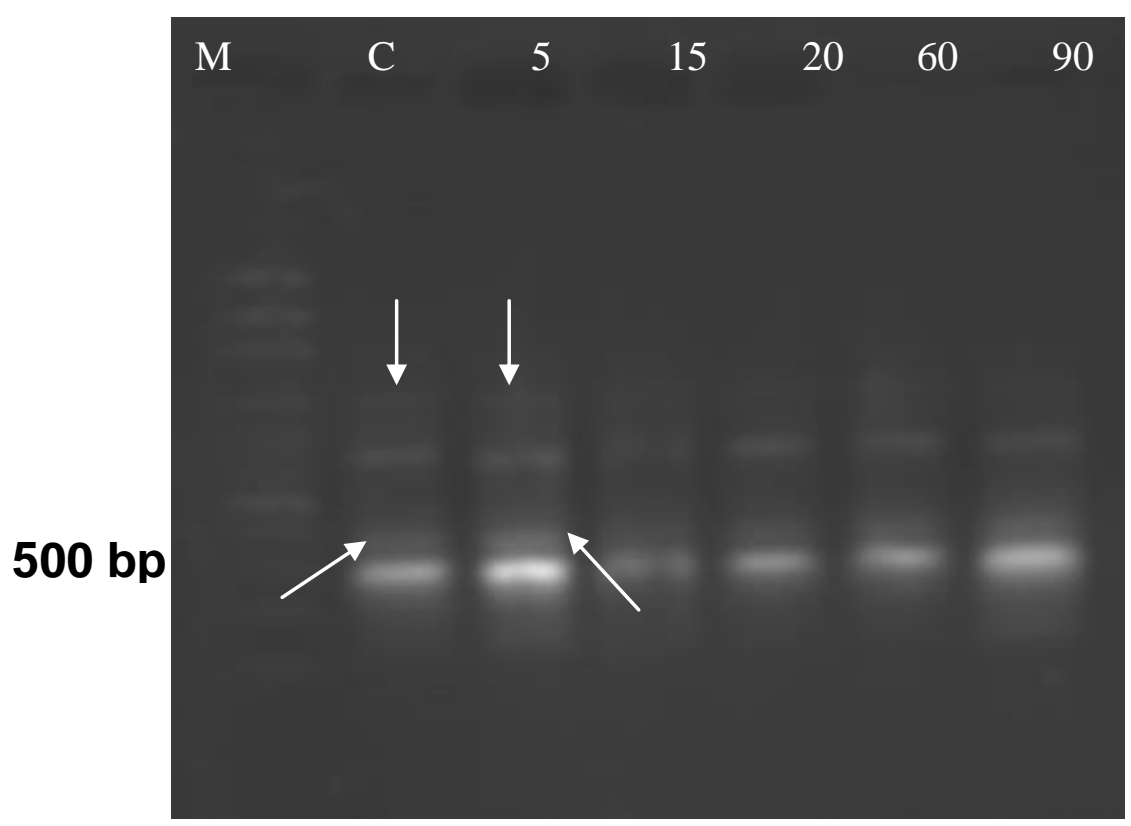

Fig. 2. RAPD profile using primer OPD-05 with genomic DNA isolated from bacteriophage $A 8$ exposed to UV-C radiation for different time periods. Lane M, molecular marker; lane $C$, control (without UV-C exposure); lane 3, 5 min exposure; lane 4, 15 $\mathrm{min}$; lane 5, $30 \mathrm{~min}$; lane 6, $60 \mathrm{~min}$ and lane 7, $90 \mathrm{~min}$. 


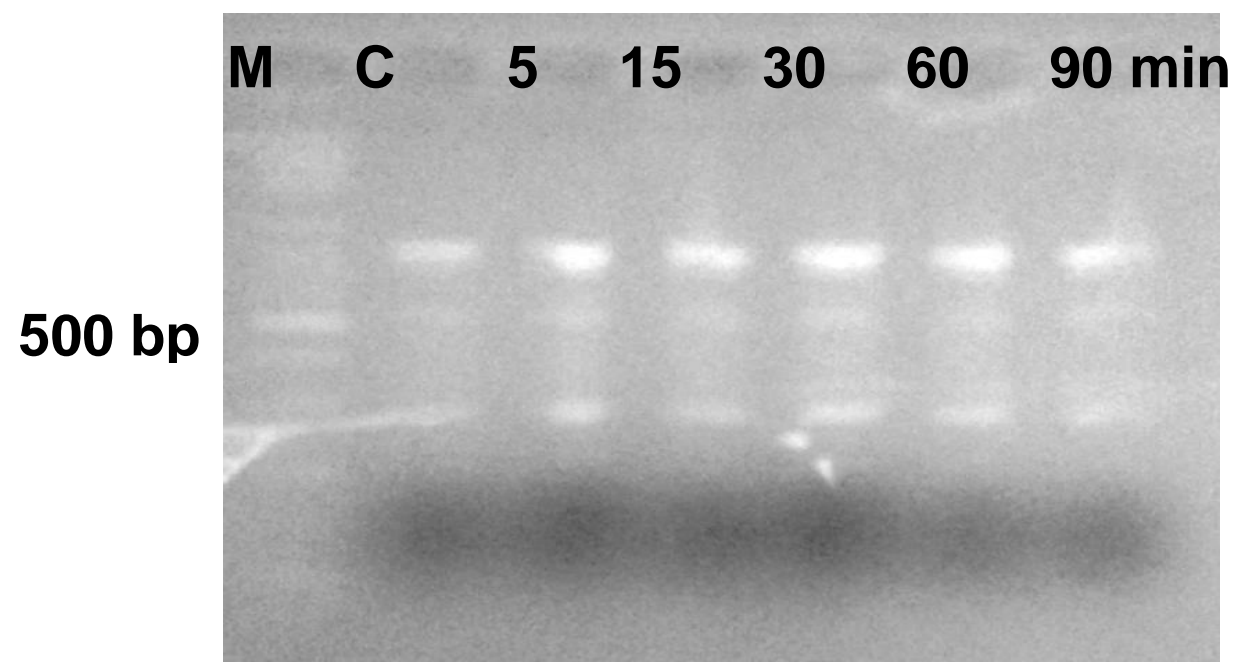

Fig. 3. RAPD profile using primer OPD-05 with genomic DNA isolated from bacteriophage $R 3$ exposed to UV-C radiation for different time periods. Lane M, molecular marker; lane $\mathrm{C}$, control (without UV-C exposure); lane 3, 5 min exposure; lane 4, 15 min; lane 5, $30 \mathrm{~min}$; lane 6, $60 \mathrm{~min}$ and lane 7, $90 \mathrm{~m}$

\section{Effect of gamma ray on DNA polymorphism using RAPD-PCR}

Gamma irradiation produced oxygen radicals generated by the hydrolysis of water (Puchala and Schessler, 1993) and could induce chromosomal rearrangements (Nagy et al., 1997). In this study, $10 \mathrm{ml}$ of phage lysats were irradiated using different doses of gamma rays including 0,200 , $400,600,800$ and 1000 KGy. RAPD assay was employed to detect genomic alterations and it could clearly show that some DNA changes had occurred in treated bacteriophages. Five primers chosen from the initial screening process were OPA-06, OPC-08, OPC-20, OPD-03 and OPD-05 (Table 1). Total number of amplified fragments from all primers for untreated and each treated bacteriophages with gamma ray are summarized in Table 3 . Each of five different random primers yielded from 3 to 5 DNA fragments whose molecular size ranged from approximately 285 to $1000 \mathrm{bp}$. The total number of amplified RAPD fragments after using all five primers was 22 bands with an average of 4.4 fragments / primer. The number of polymorphic bands through each primer ranged from 1 to 4 bands per primer with an average of 2.4 polymorphic bands per primer. The total number of polymorphic amplicons produced by the 5 primers was 12 , which representing a polymorphism level of $54.54 \%$ at all. Primer OPD-03 produced the lowest number of fragments ( 3 bands) and produced the lowest percentage of polymorphism (33.33\%) among the primers, while primer OPC-20 produced the highest percentage of polymorphism (80\%).

In this study, RAPD assay showed changes in number and presence or absence of some amplified bands between control and treated 
bacteriophages. The result of RAPD analysis indicted the appearance of DNA polymorphic bands in response to treatment with doses of all gamma irradiation. Some bands present in the control disappeared in treated bacteriophages or vice versa. Differences were apparent as the appearance of new amplified bands or the disappearance of some bands. The disappearance of bands in the treated bacteriophages may be related to such events as DNA damage (single or double strand breaks, modified bases site, oxidized bases, and bulky adducts), DNA-protein cross links, point mutations and complex chromosomal rearrangements induced by gamma irradiation (Ginchner et al., 2008). However the appearance of new bands could be attributed to mutation rather than DNA damage (Hadrys et al., 1992 and Atienzar and Jha, 2006).The fragment size of the PCR products generated by primer OPA-06 (Figs. 4 and 5) ranged from approximately 285 to $950 \mathrm{bp}$. Molecular size of bands was approximately 700 and $950 \mathrm{bp}$ as appeared under all the effects of gamma irradiation in bacteriophage A8 and disappeared under control, while in bacteriophage R3 two bands were appeared under irradiation by 800 and 1000 Gy. The appearance of new bands could be attributed to mutation rather than DNA damage (Hadrys et al., 1992 and Atienzar and Jha, 2006).

Irradiation was well known as the best physical mutagen which dissociates water molecules and produces hydroxyl radicals and causes oxidative damage (Ginchner et al., 2008). The free radicals interact with biomolecules including DNA and scavenge electrons from them. This imposes damage to the structure and the activity of DNA. When Taq polymerase encounters a damaged DNA, there could be a number of outcomes such as blockage, bypass and possible dissociation of the enzyme-DNA which will cause the loss of bands. However, the appearance of new bands could be attributed to different DNA structural changes (Breaks, transpositions, deletion etc) (Danylchenko and Sorochinsky, 2005) rather than DNA damage (Atienzar and Jha, 2006).

Although genetic basis of the polymorphisms generated by RAPD is not well-defined, the RAPD assay proved useful a means of discovering genomic alterations induced by gamma rays. Gamma rays irradiation leads to increasing the level of DNA break formation. These different types of DNA damages could be detected by changes in RAPD profiles (Senthamizh et al., 2008). El-Sherbeny et al. (2005) used gamma rays and fast neutrons to induce mutation in Hansenula anomala and Rhodotorula rtubra and employed RAPD assay to track genomic changes and they reported that RAPD could detect changes in genetic make up of both yeasts. Wendt et al. (2001) used the RAPD markers to study the effect of gamma irradiation on potato. Ganapathi et al.(2008) studied the effect of gamma irradiation on banana using RAPD-DNA analysis. They observed changes in the DNA bands, where the main changes in the RAPD profiles of the present investigation were the appearance or disappearance of different bands with variation in their intensity. These effects might be due to the structural rearrangements in DNA caused by different types of DNA damages. 
Table 3. Number of amplicons and the number of polymorphic bands produced by each RAPD primer for control and all bacteriophage treated with gamma ray.

\begin{tabular}{|c|c|c|c|c|c|c|c|c|c|c|c|c|c|c|c|}
\hline \multirow[b]{2}{*}{ Primers } & \multicolumn{6}{|c|}{$\begin{array}{c}\text { A8 } \\
\text { bacteriophage }\end{array}$} & \multicolumn{6}{|c|}{$\begin{array}{c}\text { R3 } \\
\text { bacteriophage }\end{array}$} & \multirow{2}{*}{ 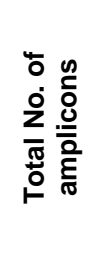 } & \multirow{2}{*}{ 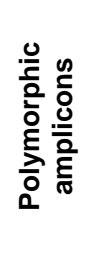 } & \multirow{2}{*}{ 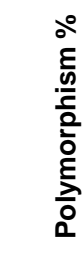 } \\
\hline & $\begin{array}{l}\overline{0} \\
\text { 옹 }\end{array}$ & 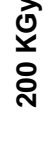 & 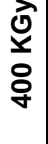 & 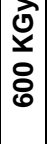 & 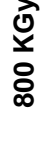 & 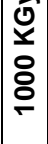 & 옿 & $\begin{array}{l}\text { ত্র } \\
\frac{\mathbf{x}}{8} \\
\text { d }\end{array}$ & 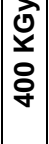 & $\begin{array}{l}\bar{j} \\
x \\
8 \\
0\end{array}$ & 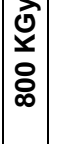 & 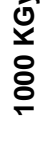 & & & \\
\hline OPA-06 & 3 & 5 & 5 & 5 & 5 & 5 & 3 & 3 & 3 & 3 & 5 & 5 & 5 & 2 & 40 \\
\hline OPC-08 & 4 & 4 & 4 & 3 & 4 & 4 & 4 & 3 & 4 & 4 & 3 & 4 & 4 & 2 & 50 \\
\hline OPC-20 & 3 & 3 & 2 & 3 & 5 & 4 & 4 & 4 & 3 & 3 & 3 & 4 & 5 & 4 & 80 \\
\hline OPD-03 & 3 & 3 & 2 & 3 & 2 & 3 & 3 & 3 & 3 & 3 & 3 & 2 & 3 & 1 & 33.33 \\
\hline OPD-05 & 5 & 3 & 3 & 4 & 3 & 4 & 4 & 3 & 3 & 3 & 4 & 4 & 5 & 3 & 60 \\
\hline Total & & & & & & & & & & & & & 22 & 12 & 54.54 \\
\hline Average & & & & & & & & & & & & & 4.4 & 2.4 & \\
\hline
\end{tabular}

Fig. 4. RAPD profile using primer OPA-06 with genomic DNA isolated from bacteriophage A8 exposed to different doses of gamma rays. Lane $\mathrm{M}$, molecular marker; lane $\mathrm{C}$, control(without gamma rays exposure); lane 3, $200 \mathrm{KGy}$; lane 4, $400 \mathrm{KGy}$; lane 5, 600 KGy; lane 6, $800 \mathrm{KGy}$ and lane 7, $900 \mathrm{KGy}$. 
Youssef, M. A. H. and Amina A. Hassan

Fig. 5. RAPD profile using primer OPA-06 with genomic DNA isolated from bacteriophage R3 exposed to different doses of gamma rays. Lane $\mathrm{M}$, molecular marker; lane $\mathrm{C}$, control(without gamma rays exposure); lane 3, $200 \mathrm{KGy}$; lane 4, $400 \mathrm{KGy}$; lane 5, 600 KGy; lane 6, $800 \mathrm{KGy}$ and lane 7, $900 \mathrm{KGy}$.

\section{Chemical inactivation:}

The first chemical agent was chlorine, it supplied as sodium hypochlorite. Residual chlorine was neutralized by the addition of sodium thiosulphate. Two concentrations of chlorine were used $(0.5$ and $1.0 \mathrm{mg} / \mathrm{ml})$. In this study Fig. 6 ( $a$ and $b$ ) shows intermediate effects of chlorine on A8 and R3 phages. PFU/ml was decreased 2 log for phage A8 and 4 log for phage R3.

Previous studies were showed differences in the $\log _{10}$ reduction of the various viruses and bacteriophages. According to Maillard et al. (1998) phage F116, active against $P$. aeruginosa PAO1, was highly sensitive to low concentrations (5 and $75 \mathrm{ppm}$ ) of sodium hypochlrite, achieving at least a 4 $\log _{10}$. Studies on L.helveticus (Quiberoni et al., 1999) and S. thermophilus phages (Binetti and Reinheimer, 2000) showed a complete inactivation when 100 ppm residual - free chlorine was supplied.

Inactivation of phages B40- 8 and SS13 were not significantly different, but phages SR 51, MY 2 and $\varnothing \times 174$ were a greater inactivation (Duran et al., 2003). Quiberoni et al. (2003) reported that sodium hypochlorite at $200-$ $400 \mathrm{ppm}$ inactivated the tested phages completely except phage lb3 which was only destroyed after treatment with $1200 \mathrm{ppm}$, so, the effectiveness of sodium hypochorite was phage dependents. 
The results in Fig. 6 (c and d), (e and f) shows isopropanol and ethanol inactivation respectively, concentration of $80 \%$ was more efficient than $40 \%$ for both phages. It is fined a dose response between the concentration and time of treatment. Phage R3 is sensitive than A8, it is totally inactivation at 90 min. Isopropanol is less effective than ethanol. Ethanol at concentration of $80 \%$ inactivated all phage A8 population in 90 min and phage R3 in 15 min. These results are consistent with the results of other authors, Quiberoni et al. (2003) found that $10 \%$ concentration of isopropanol had no effect on phage viability and only low reductions were observed after 45 min with $50 \%$ or $100 \%$, ethanol at a concentration of $100 \%$ produced the fastest inactivation of viral particles. Buzrul et al. (2007) reported that ethanol at a concentration $75 \%$ inactivated all the phage populations at $1 \mathrm{~min}$, however, isopropanol at the same concentration completely inactivated the population at $15 \mathrm{~min}$.

Fig. 6. Effect of some chemical agents on viability of phages $A 8$ and $R 3,(a, b)$ :chlorine inactivation,(c,d):isopropanol inactivation, $(e, f)$ :ethanol inactivation. 
These results indicated that the effect of physical or chemical agents on bacteriophages are phage dependent. Phage A8 is less affected than phage R3. Ethanol at concentration $80 \%$ and $60^{\circ} \mathrm{C}$ are more efficient treatments, it more lethal than other tested treatments for Bacillus thuringiensis bacteriophages A8 and R3.

\section{Inactivation of phages ability to gene transfer:}

Phages treated with previous physical or chemical agents were subjected to study of their ability to transfer ampicillin resistant gene. Results in Tables 4, 5, 6 and 7 shows number of transduction frequency at some treatments. For thermal inactivation $50,55,60^{\circ} \mathrm{C}$ at 20 and 120 min only were chosen. The ability of two phages in gene transfer was reduced when temperature was increased and completely inactivated at $60^{\circ} \mathrm{C}$. Ability of UV and gamma inactivated phages to transduce was found at all treatments, this may be due to reactivation repair mechanism of phage nucleic acid in the presences of bacterial host (Markus et al., 1997). But, transduction frequency was decreased from $10^{-5}$ to $10^{-8}$.

Effect of chlorine on gene transfer was low efficient, transduction frequency was decreased from $5.6 \times 10^{-5}$ to $1.3 \times 10^{-5}$. In contrast, isopropanol and ethanol completely inactivated the ability of two phages on gene transfer (data not shown). It may suggest that, this effect was due to alteration of nucleic acid and structure of phages. Maillard et al. (1996 a and b) found that peractic acid altered the nucleic acid and the viral capsid of the phage F116. Isopropanol at a concentration of $100 \%$ showed a similar effect on the same phage (Maillard et al., 1995 and Maillard et al., $1996 \mathrm{a}$ and b).

Table 4. Effect of thermal inactivation on $A 8$ and R3 phages ability to gene transfer.

\begin{tabular}{|l|c|c|c|c|}
\hline \multirow{2}{*}{ Transduction frequency } & \multicolumn{2}{|c|}{$\mathbf{2 0} \mathbf{~ m i n}$} & \multicolumn{2}{c|}{$\mathbf{1 2 0} \mathbf{~ m i n}$} \\
\cline { 2 - 5 } Temperature ( $\left.{ }^{\circ} \mathbf{C}\right)$ & $\mathbf{A 8}$ & $\mathbf{R 3}$ & $\mathbf{A 8}$ & $\mathbf{R 3}$ \\
\hline $\mathbf{5 0}$ & $6.1 \times 10^{-6}$ & $5.4 \times 10^{-6}$ & $3.6 \times 10^{-1}$ & $2.2 \times 10^{-1}$ \\
\hline $\mathbf{5 5}$ & $3.5 \times 10^{-6}$ & $2.4 \times 10^{-6}$ & $3.2 \times 10^{-8}$ & $1.2 \times 10^{-8}$ \\
\hline $\mathbf{6 0}$ & 0 & 0 & 0 & 0 \\
\hline
\end{tabular}

Transduction frequency of non-treated phages: $A 8=7.8 \times 10^{-5}, R 3=2.3 \times 10^{-5}$

Table 5. Effect of UV inactivation on the ability of A8 and R3 phages to gene transfer.

\begin{tabular}{|l|c|c|}
\hline \multirow{2}{*}{ Dose (min) } & \multicolumn{2}{|c|}{ Transduction frequency } \\
\cline { 2 - 3 } & $\mathbf{A 8}$ & $\mathbf{R 3}$ \\
\hline $\mathbf{0}$ & $5.6 \times 10^{-5}$ & $1.3 \times 10^{-5}$ \\
\hline $\mathbf{5}$ & $5.1 \times 10^{-5}$ & $1.2 \times 10^{-5}$ \\
\hline $\mathbf{1 5}$ & $4.2 \times 10^{-5}$ & $1.0 \times 10^{-5}$ \\
\hline $\mathbf{3 0}$ & $9.8 \times 10^{-1}$ & $4.0 \times 1-^{-}$ \\
\hline $\mathbf{6 0}$ & $1.3 \times 10^{-1}$ & $1.1 \times 10^{-1}$ \\
\hline $\mathbf{9 0}$ & $4.2 \times 10^{-8}$ & $1.0 \times 10^{-8}$ \\
\hline
\end{tabular}


Table 6. Effect of gamma inactivation on the ability of A8 and R3 phages to gene transfer.

\begin{tabular}{|l|c|c|}
\hline \multirow{2}{*}{ Dose (Gry) } & \multicolumn{2}{|c|}{ Transduction frequency } \\
\cline { 2 - 3 } & $\mathbf{A 8}$ & $\mathbf{R 3}$ \\
\hline $\mathbf{0}$ & $3.7 \times 10^{-5}$ & $3.8 \times 10^{-5}$ \\
\hline $\mathbf{2 0 0}$ & $3.8 \times 10^{-5}$ & $1.9 \times 10^{-5}$ \\
\hline $\mathbf{4 0 0}$ & $1.2 \times 10^{-6}$ & $8.7 \times 10^{-6}$ \\
\hline $\mathbf{6 0 0}$ & $9.8 \times 10^{-1}$ & $6.1 \times 10^{-}$ \\
\hline $\mathbf{8 0 0}$ & $1.3 \times 10^{-1}$ & $7.0 \times 10^{-1}$ \\
\hline $\mathbf{1 0 0 0}$ & $2.0 \times 10^{-8}$ & $2.5 \times 10^{-8}$ \\
\hline
\end{tabular}

Table 7. Effect of chlorine inactivation on the ability of phage A8 and R3 to gene transfer.

\begin{tabular}{|l|c|c|}
\hline \multirow{2}{*}{ Concentration $(\mathrm{mg} / \mathrm{ml})$} & \multicolumn{2}{|c|}{ Transduction frequency } \\
\cline { 2 - 3 } & $\mathbf{A 8}$ & $\mathbf{R 3}$ \\
\hline Non- treated phage & $5.6 \times 10^{-5}$ & $5.3 \times 10^{-5}$ \\
\hline $\mathbf{0 . 5}$ & $3.8 \times 10^{-5}$ & $3.5 \times 10^{-5}$ \\
\hline $\mathbf{1 . 0}$ & $3.1 \times 10^{-5}$ & $1.3 \times 10^{-5}$ \\
\hline
\end{tabular}

In this study a very high diversity of phage inactivation was distinguished for physical and chemical tested agents against Bacillus thuringiensis bacteriophages $\mathrm{A} 8$ and R3 which were used as a model in this investigation. The kind of information obtained was important to outline the most effective thermal and some chemical treatment for inactivation of bacteriophages in laboratories, industries and environments.

\section{REFERENCES}

Atienzar, F. and A. N. Jha (2006). The amplified polymorphic DNA (RAPD) assay and related techniques applied to genotoxicity and carcinogenesis studies: A critical review. Mut Res., 613: 76-102.

Atienzar, F. A., P. Venier, A. N. Jha and M. H. Depledge (2002). Evaluation of the random amplified polymorphic DNA (RAPD) assay for the detection of DNA damage and mutations. Mut Res., 521: 151-163

Binetti, A. G. and J. A. Reinheimer (2000). Thermal and chemical inactivation of indigenous streptococcus thermophilus bacteriophages isolated from Argentinian dairy plants. J. of Food Protection, 63: 509-515.

Bonnie, B. (2005). A Comparison of the effect of microwave irradiation and heat treatment of $\mathrm{T} 4$ and $\mathrm{T} 7$ bacteriophage. J. of Experimental Microbiology and Immunology, 7: 57-61.

Bryant, S., R. Rahmanian, H. Tam and S. Zabetian (2007). Effect of microwave irradiation and heat on T4, bacteriophage. $\mathrm{J}$. of Experimental Microbiology and Immunology, 11:66-72.

Buzrul, S., P. Ozturk, H. Alpas and M. Akcelik (2007). Thermal and chemical inactivation of lactococcal bacteriophages. LWT, 40: 1671-1677.

Danon, A. and P. Gallois (1998). UV-C radiation induces apoptotic-like changes in Arabidopsis thaliana. FEBS Letters, 437: 131-136.

Danylchenko O. and B. Sorochinsky (2005). Use of RAPD assay for the detection of mutation changes in plant DNA induced by UV-B and Rrays BMC plant. Biology, 5:1-5. 
Dhakshanamorthy, D., R. Selvaraj and A. Chidambaram (2011). Induced mutagenesis in Jatropha curas L. using gamma rays and detection of DNA polymorphism through RAPD marker. Competes Rendus Biologies., 334: 24-30.

Duran, A. E., M. Muniesa, L. Moce-Llivina, C. Campos, J. Jofre and F. Lucena (2003). Usefulness of different groups of bacteriophages as model micro-organisms for evaluating chlorination. J. of Appl. Microbiol., 95: 29-37.

El-Sherbeny, S., M. Hanafy, A. Hassan and M. Amin (2005). RAPD analysis of DNA polymorphism in the yeast Hanssenula anomala and Rhodotorula rubra irradiated by gamma and fast neutrons. Int J Agri Biol., 7: 942-946.

Farooq, S., C. N. Kurucz, T. D. Waite and W. J. Cooper (1993). Disinfection of waste waters: high- energy electron vs gamma irradiation Water Res., 27: 1177-1184.

Ganapathi, T. R., S. Meenakshi, P. Suprasanna, K. Ujjappa, V. A. Bapat and S. F. D'Souza (2008). Field performance and RAPD analysis of gamma-irradiated variants of banana cultivar 'Giant Cavendish' (AAA) Int. J. Fruit Sci., 8: 147-159.

Ginchner, T., I. Zindar and J. Szakova (2008). Evaluation of DNA damage and mutagenecity induced by lead in tobacco plants. Mut Res., 652: 186-190.

Hadrys, H., M. Balick and B. Schierwater (1992). Applications of random amplified polymorphic DNA (RAPD) in molecular ecology. Mol Ecol.; 1: 55-63.

Hassan, A. A. and M. A. H. Youssef (2011). Isolation and characterization of Bacillus thuringiensis bacteriophages using electron microscope and RAPD - PCR. J. Agric. Chem and Biotechn., Mansora univ., 2:343359.

Hernandez, P, A. Martin and G. Dorado (1999). Development of SCARS of RAPD products. Mol Breed., 3: 245-253.

Jones, C. and A. Kortenkamp (2000). RAPD library fingerprinting of bacterial and human DNA: applications in mutation detection. Teratog Carcinog Mutagen., 20:49-63.

Kaberi, D. and V. Naresh (1998). Exposure to low dose of gamma radiation enhances the excision repair in Saccharomyces cerivisiae. J Gen App Microb., 44: 243-249.

Lagunas-Solar, M. C. (1995). Radiation processing of foods: an overview of scientific and current status. J. Food Prot., 58: 186-192.

Maillard, J. Y., A. C. Hann, T. S. Beggs, M. J. Day, R. A. Hudson and A. D. Russel (1995). Electronmicroscopic investigation of the effects of biocides on Pseudomonas aeruginosa PAO1 bacteriophage F116. J. of medical microbiology, 42: 415-420.

Maillard, J. Y., A. C. Hann, V. Baubet and R. Perrin (1998). Efficacy and mechanisms of action of sodium hypochorite on Pseudomonas aeruginosa PAO1 phage F116. J. of Appl. Bacteriol., 85: 925-932. 
Maillard, J. Y., T. S. Beggs, M. J. Day, R. A. Hudson and A. D. Russel (1996a). The effect of biocides on proteins of Pseudomonas aeruginosa PAO1 bacteriophage F116. J. of Appl. Bacteriol., 80: 291295.

Maillard, J. Y., T. S. Beggs, M. J. Day, R. A. Hudson and A. D. Russel (1996b). Damage to Pseudomonas aeruginosa PAO1 bacteriophage F116 DNA by biocides. J. of Appl. Bacteriol., 80: 540-544.

Manabe, M., T. Ino, M. Kasaya, I. Takum and O. Nakamura (1999). Segregation distortion through female gametophytes in inter-specific hybrids of wheat as revealed by RAPD A analysis. Herediats., 131: 47-53.

Markus, G., W. W. Steven, A. W. Curtis and D. R. Garza (1997). Photoreactivation compensates for UV damage and restores infectivity to natural marine virus communities. Appl. Environ. Microbiol., 63: 2200-2205.

Muller, M. M., T. Rauscher and J. Hinrichs (2005). Inactivation of bacteriophages by thermal and high-Pressure treatment. International Dairy Journal, 15: 777 - 784 .

Nagy, A., Z. Palagy, L. Ferenczy and C. Vagvolgy (1997). Radiation induced chromosomal rearrangement as an aid to analysis of the genetic constitution of Phaffia rhodozyma FEMS Microb Lett., 152: 249-254

Palágyi, Z., T. Papp, M. Takó, Á. Nagy, M. Pesti and C. Vágvölgy (2004). Genetic variability of astaxanthin-producing yeasts: random amplified polymorphic DNA (RAPD) analysis of Phaffia rhodozyma and Xanthopyllomyces dendrorhous. Acta Biologica Szegediensis., 48: 3538.

Peleg, M. (2002). Modeling and simulation of microbial survival during treatments with a dissipating lethal chemical agent. Food Research international, $35:$ 327-336.

Prior, S. E., A. J. Andrews and R. O. Nordeen (2007). Characterization of bacteriophages of Pseudomonas syrringae pv. Tomato. J. of the Arkansas of Science, 16: 84-89.

Puchala, M. and H. Schessler (1993). Oxygen effect in the radiolysis of proteins. Int J Radiat Biol., 64: 149-156.

Quiberoni, A., D. M. Guglielmotti and J. A. Reinheimer (2003). Inactivation of lactobacillus delbrueckii bacteriophages by heat and biocides. International J. of food microbiology, 84:51-62.

Quiberoni, A., V. B. Suarez and J. A. Reinheimer (1999). Inactivation of Lactobacillus bacteriophages by thermal and chemical treatments. J. of Food Production, 62: 894-898

Said, M. B., A. Hassen, N. Saidi and H. W. Achermann (2009). Study of the relationship between bacteriophages and selective host cells according to different conditions of UV-C irradiation. Desalination, 248: 76-87.

Senthamizh, S. B., V. Ponnuswami and P. S. Kavitha (2008). Use of RAPD assay for the detection of mutation changes in aonla (Emblica officinalis Gaertn.). Adv. Nat. Appl. Sci., 2: 129-134

Sinha, R. P. and D. P. Hader. (2002). Life under solar UV radiation in aquatic organisms, Adv. Space Res., 30: 1547-1556. 


\section{Youssef, M. A. H. and Amina A. Hassan}

Sommer, R., W. Pribil, S. Appelt, P. Gehringer, H. Eschweiler, H. Leth, A. Cabaj and T. Haider (2001). Inactivation of bacteriophages in water by means of non- ionizing (UV- $253.7 \mathrm{~nm}$ ) and ionizing (Gamma) radiation: a Comparative approach. Wat. Res., 35:3109-3116.

Welsh, J. and M. McClelland (1990). Fingerprinting genomes using PCR with arbitrary primers. Nucleic Acids Res., 18: 7213-7218.

Wendt, S. N., J. A. Peters, A. C. Oliveira, V. L. Bobrowski, E. C. Cosa, C. S. Madruga and I. L. Vighi (2001). Plant regeneration and molecular characterization of potato cultivar Macaca, obtained from gamma irradiation explants. J. New Seeds, 3: 17-37.

Williams, J. G. K.; A. R. Kubelik; K. J. Livak; J. A. Rafalski and S. V. Tingey (1990). DNA polymorphisms amplified by arbitrary primers are useful as genetic markers. Nucleic Acids Res., 18: 6531-6535.

Wommack, K. E. and R. R. Colwell (2000). Virioplankton: viruses in aquatic ecosystems. Microbiol. Mol. Biol. Rev., 64: 69-114.

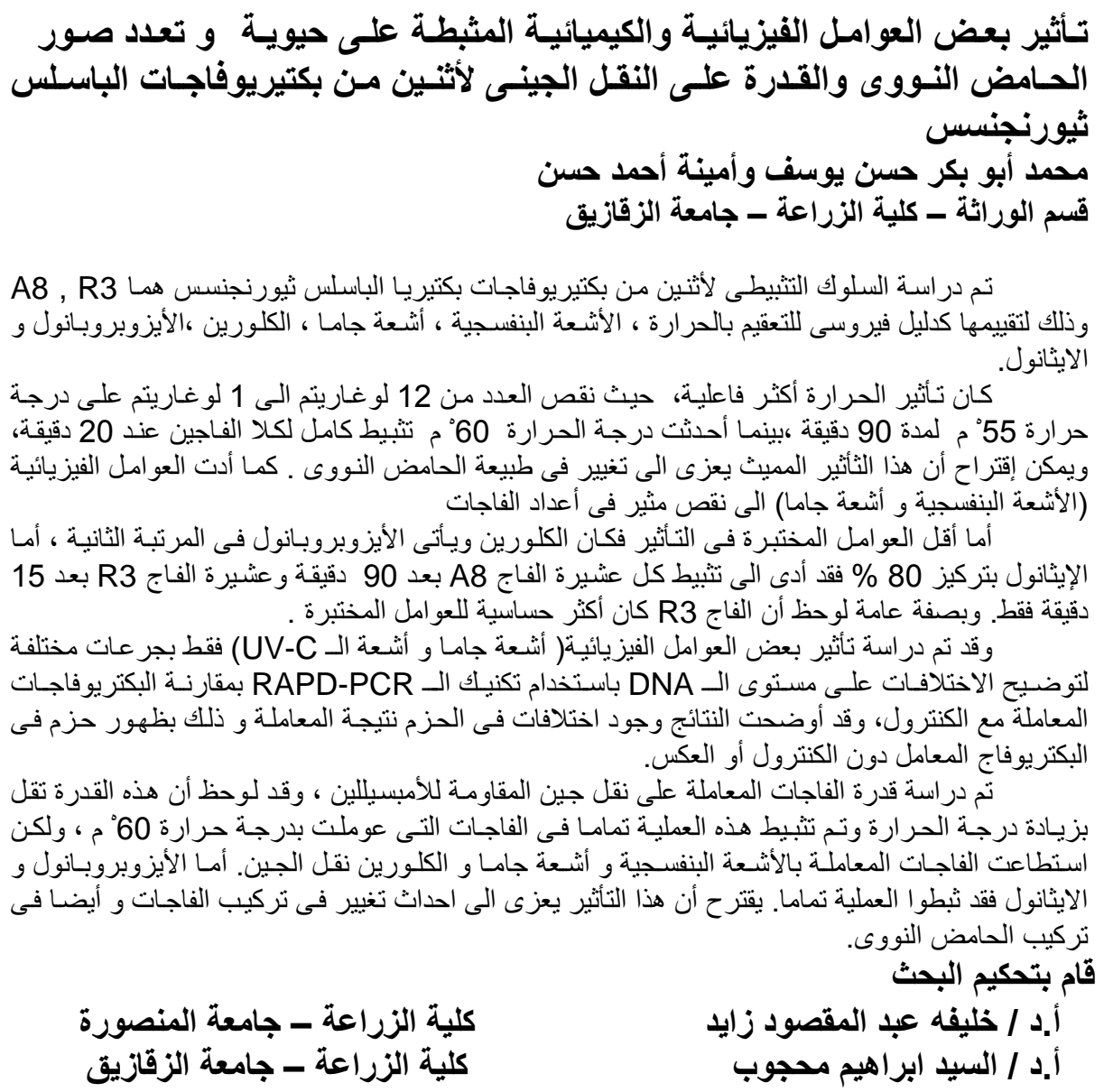

